\title{
Opinion and Relationship of the Farmer of towards Mobile Based Agro-Advisory Services
}

\author{
M.B. Gawali*, D.D. Suradkar and M.B. Shinde \\ Department of Extension Education, College of Agriculture, Latur, Vasantrao Naik \\ Marathwada Krishi Vidyapeeth, Parbhani-431402 (M.S.) India \\ *Corresponding author
}

Keywords

Mobile based agroadvisory service, Opinion, ICT, IFFCO

Article Info

Accepted:

04 June 2019

Available Online:

10 July 2019

A B S T R A C T

The study was conducted in Latur district of Marathwada region. Population for the study comprised of respondents who were subscriber of Mobile based agro- Advisory Services in Latur district. From latur district Latur, Ausa and Renapur tahsils were selected purposively because more number of farmers in these tahsils were using mobile based agro-advisory service. Proportionate sampling method used in selection of respondents, thus total sample size was one hundred and twenty respondents. One shot case study method of ex-post-facto research design was adopted for this study. Data was coded, tabulated, analysed and interpreted using suitable statistical parameters. The results showed that most of the users $(62.50 \%)$ had somewhat satisfied and independent variables like education, land holding, cropping pattern, annual income, social participation, extension contact, innovativeness and risk preference had positive and significant relationship with utility perception. Whereas land holding and annual income were do not showed significant relationship with utility perception.

\section{Introduction}

Information and Communication Technology (ICT) is an umbrella term that includes computer hardware and software, digital broadcast and telecommunication technologies as well as digital information repositories online or offline (Arendt, 2007). Organizations like IFFCO Kisan Sanchar limited and KVKs are providing agricultural services on mobile. IFFCO Kisan Sanchar limited providing services like free voice messages and SMS services related to various aspects of agriculture. Using mobile based agro-advisory services enhance the chances of rural income generation to achieve agricultural development goals by supplementary investments, resources, and strategies. First, better information may lead farmers to make better allocation of production factors. 
Second, information can improve the bargaining position of the small farmers and improve competition between traders. Thirdly, given the provision of alternative nearby markets, farmers can use the information to switch between end markets. Therefore it is important to know the advisory services of keeping this into consideration the present study with following objectives:

To study profile of farmers of mobile based agro-advisory service. To find out the relationship between the profile characteristics of farmers with their opinion of mobile based agro-advisory service.

\section{Materials and Methods}

Population for the study comprised of respondents who were subscriber of mobile based agro- Advisory Services in Latur district. From latur district Latur, Ausa and Renapur tahsils were selected purposively because more number of farmers in these tahsils was using mobile based agro-advisory service. Proportionate sampling method used in selection of respondents, thus total sample size was one hundred and twenty respondents. One shot case study method of ex-post-facto research design was adopted for this study. The schedule of opinion was developed with help of teacher to quantify opinion of farmers about mobile based agro-advisory services was measured by computing the score. Final score was calculated by combining all scores and made as category not satisfied (upto 29), somewhat satisfied (30 to 48) and highly satisfied (49 \& above).

\section{Results and Discussion}

\section{Profile characteristics of the farmers}

The first objective of the study was to describe profile characteristics of farmers. The distributional analysis pertaining to age of the respondents indicated that, majority $(60.83 \%)$ of the respondents were from middle age group, majority $(34.17 \%)$ of the respondents belonged to secondary education category, majority 82.50 per cent respondents belonged to medium family size, 41.67 per cent respondents had semi-medium land holding (2.01 to 4 ha), majority $(75.00 \%)$ of the farmers were growing soybean followed by sorghum (54.16\%), Green gram $(40.83 \%)$ during kharif, and during rabi season majority $(73.33 \%)$ of the farmers were growing chick pea followed by wheat $(58.33 \%)$ (Table 1$)$.

Also in summer groundnut were grown while sugarcane was grown as annual. (77.50\%) respondents hadmedium annual income above (Rs.1,39,550 to 3,38,783), majority (65. $83 \%$ ) respondent had medium social participat ion, medium extension contact,(75\%) respond ents had medium innovativeness and (70.83\%) of the respondents belonged to medium risk preference.

\section{Opinion of farmers about mobile based agro-advisory service}

The distribution of the respondents according to their opinion regarding to information of crop production, market, government scheme, general characters etc.

\section{Opinion of the farmer information regarding crop production}

It could be inferred from the data presented in Table 2 that, majority of the respondents were highly satisfied with the information regarding recommended precautions taken at spraying time $(79.16 \%)$ and newly released crop variety $(66.66 \%)$, weather forecasting $(64.16 \%)$, soil testing $(58.33 \%)$, seed treatment $(54.16 \%)$, disease symptoms (47.50\%), recommended doses $(45.83 \%)$, pest attack (45.83\%), weed management (43.34\%), sowing time $(41.66 \%)$ respectively. 
Table.1 Distribution of respondents according to their characteristics

\begin{tabular}{|c|c|c|c|}
\hline Profile characters & Category & Frequency & Percentage \\
\hline \multirow[t]{3}{*}{ Age } & Young (Up to 31 year) & 25 & 20.83 \\
\hline & Middle ( 32 to 47 year) & 73 & 60.83 \\
\hline & Old (54 year and above) & 22 & 18.34 \\
\hline \multirow[t]{10}{*}{ Education } & Illiterate & 01 & 00.83 \\
\hline & Only read and write & 14 & 11.67 \\
\hline & Primary education $\left(\operatorname{Std} 1^{\text {st }}\right.$ to $\left.4^{\text {th }}\right)$ & 12 & 10.00 \\
\hline & Secondary education (Std $5^{\text {th }}$ to $\left.10^{\text {th }}\right)$ & 41 & 34.17 \\
\hline & Higher secondary education $\left(11^{\text {th }}\right.$ to $\left.12^{\text {th }}\right)$ & 39 & 32.50 \\
\hline & Diploma & 05 & 04.17 \\
\hline & Graduated & 07 & 05.83 \\
\hline & Post Graduate & 01 & 00.83 \\
\hline & Ph.D. & 00 & 00.00 \\
\hline & Other & 00 & 00.00 \\
\hline \multirow[t]{3}{*}{ Family size } & Small (Up to 3 members) & 07 & 05.83 \\
\hline & Medium (4 to 6 members) & 99 & 82.50 \\
\hline & Large (7 members and above) & 14 & 11.67 \\
\hline \multirow[t]{5}{*}{ Land holding } & Marginal (up to 1 ha) & 21 & 17.50 \\
\hline & Small (1.01 to 2.00$)$ & 26 & 21.67 \\
\hline & Semi-medium (2.01 to 4.00$)$ & 50 & 41.67 \\
\hline & Medium (4.01 to 10.00$)$ & 23 & 19.16 \\
\hline & Big (10.01 and above) & 00 & 00.00 \\
\hline Cropping pattern & & 90 & 75.00 \\
\hline \multirow[t]{6}{*}{ (Kharif) } & Soybean & & \\
\hline & Sorghum & 65 & 54.16 \\
\hline & Pigeon pea & 48 & 40.00 \\
\hline & Black gram & 25 & 20.83 \\
\hline & Green gram & 49 & 40.83 \\
\hline & Sunflower & 32 & 26.66 \\
\hline \multirow[t]{7}{*}{ (Rabi) } & Chick pea & 88 & 73.33 \\
\hline & Wheat & 70 & 58.33 \\
\hline & Sorghum & 28 & 23.33 \\
\hline & Safflower & 22 & 18.33 \\
\hline & Groundnut & 51 & 42.50 \\
\hline & Maize (Fodder) & 36 & 30.00 \\
\hline & Vegetable & 17 & 14.16 \\
\hline (Annual) & Sugarcane & 38 & 31.66 \\
\hline \multirow[t]{3}{*}{ (Perennial) } & Mango & 5 & 04.06 \\
\hline & Sapota & 2 & 01.66 \\
\hline & Banana & 2 & 01.66 \\
\hline \multirow[t]{4}{*}{ Annual income } & Low (Up to Rs.1,39,549) & 13 & 10.83 \\
\hline & Medium (Rs. $1,39,550$ to $3,38,783$ ) & 93 & 77.50 \\
\hline & High (Rs.3,38,784 and above) & 14 & 11.67 \\
\hline & High (18 and above) & 30 & 25.00 \\
\hline \multirow[t]{3}{*}{ Social participation } & Low (Up to 6) & 20 & 11.67 \\
\hline & $\operatorname{Medium(7~to~} 13)$ & 79 & 65.83 \\
\hline & High (14 and above) & 21 & 17.50 \\
\hline \multirow[t]{3}{*}{ Extension contact } & Low (Up to 12$)$ & 24 & 20.00 \\
\hline & $\operatorname{Medium}(13$ to 21$)$ & 74 & 61.67 \\
\hline & High (22 and above) & 22 & 18.33 \\
\hline \multirow[t]{3}{*}{ Innovativeness } & Low (Up to 12$)$ & 13 & 10.83 \\
\hline & Medium (13 to 18$)$ & 90 & 75.00 \\
\hline & High (19 and above) & 17 & 14.17 \\
\hline \multirow[t]{3}{*}{ Risk preference } & Low (Up to 12$)$ & 15 & 12.50 \\
\hline & Medium(13 to 18$)$ & 85 & 70.83 \\
\hline & High (19 and above) & 20 & 16.67 \\
\hline
\end{tabular}


Table.2 Distribution of the respondents according to their opinion about information of crop production

\begin{tabular}{|c|c|c|c|c|}
\hline \multirow{2}{*}{$\begin{array}{l}\text { Sl. } \\
\text { No. }\end{array}$} & \multirow{2}{*}{$\begin{array}{l}\text { Information related to } \\
\text { crop production }\end{array}$} & \multicolumn{3}{|c|}{ Opinion $(\mathrm{N}=\mathbf{1 2 0})$} \\
\hline & & $\begin{array}{c}\text { Highly } \\
\text { satisfied }\end{array}$ & $\begin{array}{c}\text { Somewhat } \\
\text { satisfied }\end{array}$ & Never satisfied \\
\hline 1 & Soil testing & $\begin{array}{c}70 \\
(58.33)\end{array}$ & $\begin{array}{c}44 \\
(36.66)\end{array}$ & $\begin{array}{c}06 \\
(05.00)\end{array}$ \\
\hline 2 & Land preparation & $\begin{array}{c}32 \\
(26.66)\end{array}$ & $\begin{array}{c}70 \\
(58.33)\end{array}$ & $\begin{array}{c}18 \\
(15.00)\end{array}$ \\
\hline 3 & Availability of seed & $\begin{array}{c}27 \\
(22.50)\end{array}$ & $\begin{array}{c}37 \\
(30.83)\end{array}$ & $\begin{array}{c}56 \\
(46.67)\end{array}$ \\
\hline 4 & Variety & $\begin{array}{c}80 \\
(66.66)\end{array}$ & $\begin{array}{c}25 \\
(20.83)\end{array}$ & $\begin{array}{c}15 \\
(12.50)\end{array}$ \\
\hline 5 & Seed treatment & $\begin{array}{c}65 \\
(54.16)\end{array}$ & $\begin{array}{c}38 \\
(31.66)\end{array}$ & $\begin{array}{c}17 \\
(14.16)\end{array}$ \\
\hline 6 & Sowing time & $\begin{array}{c}50 \\
(41.66)\end{array}$ & $\begin{array}{c}40 \\
(33.33)\end{array}$ & $\begin{array}{c}30 \\
(25.00)\end{array}$ \\
\hline 7 & Method of sowing & $\begin{array}{c}37 \\
(30.83)\end{array}$ & $\begin{array}{c}66 \\
(55.00)\end{array}$ & $\begin{array}{c}17 \\
(14.16)\end{array}$ \\
\hline 8 & Irrigation & $\begin{array}{c}35 \\
(29.16)\end{array}$ & $\begin{array}{c}60 \\
(50.00)\end{array}$ & $\begin{array}{c}25 \\
(20.84)\end{array}$ \\
\hline 9 & Weed management & $\begin{array}{c}52 \\
(43.34)\end{array}$ & $\begin{array}{c}50 \\
(41.66)\end{array}$ & $\begin{array}{c}18 \\
(15.00)\end{array}$ \\
\hline 10 & Chemical fertilizer & $\begin{array}{c}43 \\
(35.83)\end{array}$ & $\begin{array}{c}60 \\
(50.00)\end{array}$ & $\begin{array}{c}17 \\
(14.17)\end{array}$ \\
\hline 11 & Pest attack & $\begin{array}{c}55 \\
(45.83)\end{array}$ & $\begin{array}{c}49 \\
(40.83)\end{array}$ & $\begin{array}{c}16 \\
(13.34)\end{array}$ \\
\hline 12 & Bio agent & $\begin{array}{c}20 \\
(18.34)\end{array}$ & $\begin{array}{c}59 \\
(49.16)\end{array}$ & $\begin{array}{c}39 \\
(32.50)\end{array}$ \\
\hline 13 & Disease symptoms & $\begin{array}{c}57 \\
(47.50)\end{array}$ & $\begin{array}{c}44 \\
(36.66)\end{array}$ & $\begin{array}{c}19 \\
(15.84)\end{array}$ \\
\hline 14 & Precaution while spraying & $\begin{array}{c}95 \\
(79.16)\end{array}$ & $\begin{array}{c}23 \\
(19.17)\end{array}$ & $\begin{array}{c}02 \\
(01.67)\end{array}$ \\
\hline 15 & Recommended doses & $\begin{array}{c}55 \\
(45.83)\end{array}$ & $\begin{array}{c}58 \\
(48.33)\end{array}$ & $\begin{array}{c}07 \\
(05.83)\end{array}$ \\
\hline 16 & Deficiency symptom & $\begin{array}{c}40 \\
(33.33)\end{array}$ & $\begin{array}{c}63 \\
(52.50)\end{array}$ & $\begin{array}{c}17 \\
(14.16)\end{array}$ \\
\hline 17 & Crop maturity & $\begin{array}{c}36 \\
(30.00)\end{array}$ & $\begin{array}{c}65 \\
(54.16)\end{array}$ & $\begin{array}{c}19 \\
(15.83)\end{array}$ \\
\hline 18 & Weather forecasting & $\begin{array}{c}77 \\
(64.16)\end{array}$ & $\begin{array}{c}46 \\
(38.33)\end{array}$ & $\begin{array}{c}07 \\
(05.83)\end{array}$ \\
\hline
\end{tabular}


Table.3 Distribution of the respondents according to their opinion about information of market

\begin{tabular}{|c|l|c|c|c|}
\hline Sl. No & Information about & \multicolumn{3}{|c|}{ Opinion (N=120) } \\
\cline { 3 - 5 } & market & $\begin{array}{c}\text { Highly } \\
\text { satisfied }\end{array}$ & $\begin{array}{c}\text { Somewhat } \\
\text { satisfied }\end{array}$ & Not satisfied \\
\hline $\mathbf{1}$ & $\begin{array}{l}\text { Availability of } \\
\text { market }\end{array}$ & $\begin{array}{c}39 \\
(32.50)\end{array}$ & $\begin{array}{c}75 \\
(62.50)\end{array}$ & 06 \\
\hline $\mathbf{2}$ & Market price & 70 & 47 & $05.00)$ \\
\hline $\mathbf{3}$ & Price forecasting & $(58.33)$ & $(39.16)$ & $(02.50)$ \\
\hline & & 58 & 60 & 02 \\
$(48.33)$ & $(50.00)$ & $(01.67)$ \\
\hline
\end{tabular}

Table.4 Distribution of the respondents according to their opinion in terms of satisfaction regarding to information of government schemes

\begin{tabular}{|c|c|c|c|c|}
\hline \multirow[t]{2}{*}{ Sl. No } & \multirow{2}{*}{$\begin{array}{c}\text { Information about Govt. } \\
\text { Schemes }\end{array}$} & \multicolumn{3}{|c|}{ Opinion $(\mathrm{N}=120)$} \\
\hline & & $\begin{array}{l}\text { Highly } \\
\text { Satisfied }\end{array}$ & $\begin{array}{l}\text { Somewhat } \\
\text { Satisfied }\end{array}$ & $\begin{array}{c}\text { Never } \\
\text { Satisfied }\end{array}$ \\
\hline 1 & $\begin{array}{l}\text { Newly launched govt. } \\
\text { Schemes }\end{array}$ & $\begin{array}{c}90 \\
(75.00)\end{array}$ & $\begin{array}{c}28 \\
(23.33)\end{array}$ & $\begin{array}{c}02 \\
(01.67)\end{array}$ \\
\hline 2 & $\begin{array}{l}\text { Required documents for } \\
\text { schemes }\end{array}$ & $\begin{array}{c}85 \\
(70.83)\end{array}$ & $\begin{array}{c}28 \\
(23.33)\end{array}$ & $\begin{array}{c}07 \\
(05.84)\end{array}$ \\
\hline 3 & $\begin{array}{l}\text { Eligibility criteria for } \\
\text { particular schemes }\end{array}$ & $\begin{array}{c}92 \\
(76.67)\end{array}$ & $\begin{array}{c}26 \\
(21.67)\end{array}$ & $\begin{array}{c}02 \\
(01.66)\end{array}$ \\
\hline 4 & $\begin{array}{l}\text { Important dates related to } \\
\text { particular schemes }\end{array}$ & $\begin{array}{c}89 \\
(74.16)\end{array}$ & $\begin{array}{c}26 \\
(21.67)\end{array}$ & $\begin{array}{c}05 \\
(04.17)\end{array}$ \\
\hline
\end{tabular}

Table.5 Distribution of the respondents according to their opinion about general characters of agro advisory services

\begin{tabular}{|c|c|c|c|c|}
\hline \multirow[t]{2}{*}{ Sl. No } & \multirow{2}{*}{$\begin{array}{c}\text { General characters of agro } \\
\text { advisory service }\end{array}$} & \multicolumn{3}{|c|}{ Opinion $(\mathrm{N}=120)$} \\
\hline & & Highly satisfied & $\begin{array}{c}\text { Somewhat } \\
\text { satisfied }\end{array}$ & Not satisfied \\
\hline 1 & Frequency of SMS & $\begin{array}{c}44 \\
(36.66)\end{array}$ & $\begin{array}{c}70 \\
(58.34)\end{array}$ & $\begin{array}{c}06 \\
(05.00)\end{array}$ \\
\hline 2 & Language of SMS & $\begin{array}{c}79 \\
(65.83)\end{array}$ & $\begin{array}{c}35 \\
(29.17)\end{array}$ & $\begin{array}{c}06 \\
(05.00)\end{array}$ \\
\hline
\end{tabular}

Table.6 Distribution of the respondents according to their overall opinion

$(\mathrm{N}=120)$

\begin{tabular}{|c|l|c|c|}
\hline Sl. No. & Opinion & Frequency & Percentage \\
\hline 1. & Not satisfied (Up to 29) & 19 & 15.83 \\
\hline 2. & Somewhat satisfied (30 to 48) & 75 & 62.50 \\
\hline 3. & Highly satisfied (49 and above) & 26 & 21.67 \\
\hline
\end{tabular}


Table.7 Relationship between independent and dependent variables

\begin{tabular}{|c|l|c|}
\hline Sl. No. & Independent variable & Opinion ' $\mathbf{r}$ ' values \\
\hline $\mathbf{1}$ & Age & $0.110^{\text {NS }}$ \\
\hline $\mathbf{2}$ & Education & $0.341^{* *}$ \\
\hline $\mathbf{3}$ & Family size & $0.028^{\text {NS }}$ \\
\hline $\mathbf{4}$ & Land holding & $0.220^{*}$ \\
\hline $\mathbf{5}$ & Cropping pattern & $0.226^{*}$ \\
\hline $\mathbf{6}$ & Annual income & $0.213^{*}$ \\
\hline $\mathbf{7}$ & Social participation & $0.275^{* *}$ \\
\hline $\mathbf{8}$ & Extension contact & $0.303^{* *}$ \\
\hline $\mathbf{9}$ & Innovativeness & $0.349^{* *}$ \\
\hline $\mathbf{1 0}$ & Risk performance & $0.206^{*}$ \\
\hline
\end{tabular}

* \& ** correlation is significant at the 0.05 and 0.01 level respectively.

NS - Non significant

Whereas the respondent were also highly satisfied with Agro advisory messages related to chemical fertilizer (35.83\%) followed by deficiency symptoms (33.33\%), method of sowing (30.83\%), crop maturity $(30.00 \%)$, irrigation management $(29.16 \%)$, land preparation $(26.66 \%)$, bio-agent $(18.34 \%)$, respectively.

The majority of respondent were somewhat satisfied with agro advisory messages received in relation to crop maturity $(50.83 \%)$, land preparation $(54.16 \%)$ and method of sowing $(52.50 \%)$, respectively. The respondents were also somewhat satisfied with information about bio-agent (49.16\%), deficiency symptoms $(47.50 \%)$, irrigation time $(45.83 \%)$, chemical fertilizer $(45.84 \%)$, recommended doses of insecticide/pesticide to be used (44.17\%), weed management $(39.16 \%)$, pest attack $(37.50 \%)$, disease symptoms (36.66\%), sowing time $(35.00 \%)$, weather forecasting $(35.00 \%)$, availability of seeds $(30.83 \%)$, soil testing $(30.00 \%)$ and seed treatment practice, respectively.

The respondents were not satisfied with agro advisory information of availability of seeds (46.67\%) and bio-agents (32.50\%) respectively.
By and large majority of respondents were highly satisfied with information about precaution to be taken at spraying time, new released crop varieties, weather forecasting, seed treatment, soil testing, disease symptoms, weed management, sowing time and pest attack, respectively. The respondents were not satisfied with information about availability of seeds and information about bio-agents, respectively.

\section{Opinion of the farmer regarding information about market}

It was observed from the data presented in Table 3 that, majority of the respondents $(61.67 \%)$ were highly satisfied with the information regarding to market price of particular product whereas about 35.83 per cent were somewhat satisfied. The majority of respondent $(50.83 \%)$ were highly satisfied with the information regarding to price forecasting and about 47.50 per cent respondents were somewhat satisfied with the information regarding to price fluctuation. About information of availability of market only 35.83 per cent respondents were highly satisfied whereas 60.00 per cent respondents were somewhat satisfied with availability of market. 
Opinion of the farmer regarding to information of government schemes

From Table 4 it was observed that, great majority of respondents $(82.50 \%)$ were highly satisfied regarding to information of newly launched schemes and only 15.84 per cent respondents were somewhat satisfied. It was also observed that near about 81.66 per cent, 80.00 per cent and 79.16 per cent, respondents were highly satisfied to the information of eligibility criteria for particular schemes, important dates related to particular schemes and required documents for schemes respectively.

\section{Opinion of the farmer regarding to general characters of agro advisory services}

From the Table 5 it was observed that, majority of the respondents $(54.16 \%)$ were somewhat satisfied regarding to frequency of SMS of agro advisory service and majority of respondents $(69.16 \%)$ were highly satisfied with language of SMS of agro advisory service.

\section{Overall opinion of farmers about mobile based agro-advisory services}

It has been observed from the Table 6 majority of the respondents 62.50 were somewhat satisfied towards the mobile based agro-advisory service, 21.67 per cent of the respondents were highly satisfied and 15.83 per cent of the respondents were felt most comfortable to the use of mobile phone services. The findings are somewhat line with Ganesan et al., (2013) and Bhongale (2018).

\section{Relationship between the profile characteristics and opinion}

The results revealed that out of ten independent variables, eight variables had exhibited positive significant relationship with existing opinion of the respondents. Education, Land holding, Cropping pattern, Annual income, Social participation, Extension contact, innovativeness and Risk preference had positive correlation with opinion of the respondents at 5 per cent and 1 per cent significant level respectively. Age and Family size were non-significant (Table 7).

Profile of the respondents from the present study indicated that, the majority of the respondents from middle age, secondary level of education, medium family size, semimedium land holding, majority are grown soyabean in kharif medium annual income. Regarding the other variables like social participation, extension contact and risk preference found in medium category. Also clearly observed that, majority of the respondents had opinion about information is somewhat satisfied and utilization of information is sometime about the mobile based agro-advisory services. Study indicated that majority of the respondents were somewhat satisfied with opinion regarding to agro advisory service. Therefore it was suggested that other farmer who have not aware about the agro-advisory service, can be motivated to use of advisory service by creating awareness through mass media.

\section{References}

Bhongle, S. D., (2018). Opinion and utilization of mobile based agro advisory services by farmers in Nagpur district. M.Sc. (Agri.) Thesis (unpublished), Dr. Panjabrao Deshmukh Krishi Vidyapeeth, Akola.

Ganesan, M. K. Karthikeyan., S. Prashant. And J. Umadikar., (2013). Use of mobile multimedia agricultural advisory systems by Indian farmers: Results of a survey. J Agril Ext and Rural Dev 5:8999. 
Rana, S., (2017). Mobile-based agro advisory services (MAAS) in India: An assessment of their effectiveness. Indian Counseling AR- National Academy of Agricultural Research Management.

Sidhu H. K., (2016). Opinion and utilization of mobile based agro-advisory services by farmers. M. Sc. (Agri) Thesis. PAU,
Ludhiyana.

Sing Madan, (2015). Effectiveness of Mobile based Agro-Advisory Service in Addressing Information Need of the Stakeholders: A Case of KRISHI. Indian Journal of Extension Education, 51 (1\&2): 32-38.

\section{How to cite this article:}

Gawali, M.B., D.D. Suradkar and Shinde, M.B. 2019. Opinion and Relationship of the Farmer of towards Mobile Based Agro-Advisory Services. Int.J.Curr.Microbiol.App.Sci. 8(07): 221228. doi: https://doi.org/10.20546/ijcmas.2019.807.028 